\title{
EVALUATION OF ANTIOXIDANT ACTIVITY AND CHROMATOGRAPHIC PROFILE OF EXTRACTS FROM THE FALSE JABORANDI (PIPER ADUNCUM)
}

\author{
Ludimila S. C. Passos ${ }^{1}$, Hemerson G. de O. Silva ${ }^{1}$, Layana B. Silva ${ }^{1}$, Paulo V. D. Martins ${ }^{1}$, \\ Cícero G. V. Coelho ${ }^{1}$, Rodrigo L. Peres ${ }^{1}$, Christian Fernandes ${ }^{1}$, \\ Ezequias P. S. Filho ${ }^{1}$, Carine V. S. leggli ${ }^{2}$, Marcelo B. da Rosa ${ }^{3}$ \\ 1 Laboratory Chemistry, University of Vale do Rio Doce - School of Biological Sciences (UNIVALE), Governador \\ Valadares-MG, Brazil. \\ ${ }^{2}$ Universidade Federal do Pampa (UNIPAMPA), Uruguaiana-RS, Brazil. \\ ${ }^{3}$ Graduate Program in Pharmaceutical Sciences, Federal University of Santa Maria (UFSM), Santa Maria-RS, Brazil. \\ Corresponding author -E-mail: rodrigo.loreto@gmail.com
}

\begin{abstract}
Evaluation of the antioxidant activity and chromatographic profile of the Piper aduncum (false jaborandi) extracts. This paper describes the investigation of the chemical composition using the leaves of Piper aduncum (Piperaceae) through methods of extraction envolvind decoction, maceration and ultrasonic bath. The investigation was made by the gas chromatography-mass spectrometry/SPME. From these extracts, the antioxidant activity in the presence of a free radical DPPH was evaluated.
\end{abstract}

Keywords: Piper aduncum, DPPH, gas chromatography-mass spectrometry/SPME

\section{INTRODUCTION}

In Brazil, the species Piper aduncum, belonging to the Piperaceae family, is popularly known as false jaborandi. The family Piperaceae is pantropical, with species distributed throughout the Americas from Mexico to the south of Argentina (Yunck, 1972).

The medicinal use of false jaborandi has been reported in gynecological diseases and intestinal disorders (VAN DEN BERG, 1993 apud Souza et al., 2008), as a diuretic, antiblenoragic, carminative, digestive exciting, for ailments of the liver, to fight wildfire and treatment of chronic ulcers (Coimbra, 1994). The essential oil has a fungicide, molluscicide, acaricide, bactericide and larvicide (FAZOLIN et al., 2005). The extract produced from the leaves can be used to control the type of fungus Colletrotricum musae (Bastos \& Albuquerque, 2004). The essential oil of Piper 


\section{REGETUFSM}

Rev. Elet. em Gestão, Educação e Tecnologia Ambiental

(e-ISSN: 2236-1170)

aduncum showed activity against Clinipellis pernicious fungus, which causes plague that affects crops and cocoa cupuaçu.

This paper aims at the comparative phytochemical analysis of different extracts of leaves of Piper aduncum by gas chromatography/mass spectrometry and determines the antioxidant activity of extracts obtained by maceration, decoction and ultrasonic bath. Given the diversity of processes available for obtaining herbal, studies involving the different extraction methods, the characterization / isolation of chemical constituents and the possible pharmacological actions represent an important contribution to ensuring the effectiveness and quality of these products.

\section{EXPERIMENTAL}

\subsection{Plant material}

The Piper aduncum leaves used in this experiment was collected in the University of Vale do Rio Doce (UNIVALE), Governador Valadares-MG, Brazil. After drying in an oven with air flow controlled temperature at $40^{\circ} \mathrm{C} \pm 1 . \mathrm{l}$, the vegetable material was crushed with the help of a knife mill (Marconi - model 340).

\subsection{Extraction methods}

Piper aduncum extracts were prepared in three different procedures involving maceration, decoction and ultrasonic extraction. The main extraction conditions are described in Table 1. The best extraction time of each method was determined spectrophotometrically. In specific periods of time, aliquots of $0.1 \mathrm{~mL}$ of the extract in monitoring were added to $2.9 \mathrm{~mL}$ of ethanol and the absorbance was read at $662 \mathrm{~nm}$. The final extraction was considered when the absorbance of the extract remained constant. In three procedures were placed on the rotary evaporator to complete evaporation of the solvent, and then incubated at $40^{\circ} \mathrm{C}$ with air flow to the total dry extract. The dry extracts from the plant ethanolic solutions were prepared in the in final concentrations ranging from 0.975 to $1.5 \mathrm{mg}$.

\subsection{Solid Phase Micro Extraction (SPME)}

A volume of $50 \mu \mathrm{L}$ of dry extract of the plant at a concentration of $20 \mathrm{mg} \mathrm{mL}-1$ were mixed in a glass vial of $2 \mathrm{~mL}$ and the solvent removed in a centrifugal vacuum evaporator (Speedvac, modelo 


\section{REGETUFSM}

Rev. Elet. em Gestão, Educação e Tecnologia Ambiental

(e-ISSN: 2236-1170)

SC250, ThermoSavant, EUA) for $18 \mathrm{~h}$ at $30{ }^{\circ} \mathrm{C}$ at 10 millibar. The vial was sealed with a septum cap sealed with Teflon-coated (Supelco, USA) and heating to $90{ }^{\circ} \mathrm{C}$. The SPME fiber (polydimethylsiloxane/divinylbenzene PDMS/DVB $65 \mu \mathrm{M}$, Supelco, USA) was inserted through a manual support through the septum in the headspace for 30 minutes. After the fiber was immediately analyzed by gas chromatography.

\subsection{Chromatographic Analysis}

The analysis by gas chromatography and mass spectrometry were performed on a Shimadzu QP5050A (Shimadzu, Japan) equipped with a PTE-5 column (30m, $0.25 \mathrm{~mm}, 0.25 \mu \mathrm{M}$, Supelco, USA). The following conditions were used for all analysis: helium as carrier gas at a flow rate of $22.3 \mathrm{~mL}$ min-1 and injector temperature maintained at $230{ }^{\circ} \mathrm{C}$ The oven temperature program was as follows: $80{ }^{\circ} \mathrm{C}$ for 3 minutes then heating to $300{ }^{\circ} \mathrm{C}$ at a rate of $7{ }^{\circ} \mathrm{C}$ min- $-1,300{ }^{\circ} \mathrm{C}$ for 5 minutes. The injection was made in split mode, with a ratio of 1:10. The mass detector was programmed to scan the range of $\mathrm{m} / \mathrm{z} 50$ to 500 at a rate of 2 scans per second. The acquisition and manipulation of data were conducted using the software CLASS 5000 Shimadzu. The files of the data obtained in the analysis by GC/MS were analyzed by the software Automated Mass Deconvolution and Identification System (AMDIS) version 2.1, provided by the National Institute of Standards and Technology (NIST, USA). The structural elucidation of compounds was made through the program NIST MS Search 2.0 (NIST / EPA / NIH Mass Spectral Library, version 2002).

\subsection{Analysis of antioxidant activity}

In order to analysis the antioxidant activity was performed the assay with the free radical 2,2diphenyl-1-picrylhydrazyl (DPPH). It was prepared an ethanolic solution of DPPH in a concentration of $0.004 \%$ and has been reading in the spectrophotometer (FENTO 800XI) at a wavelength of 517 $\mathrm{nm}$. At $300 \mu \mathrm{L}$ of ethanol extract of Piper aduncum in different concentrations (0.09875 to $1.5 \mathrm{mg}$ $\mathrm{mL}-1$ ) were added to $2.70 \mathrm{~mL}$ of DPPH solution. The absorbance of the solutions was monitored 


\section{REGETUFSM}

Rev. Elet. em Gestão, Educação e Tecnologia Ambiental

(e-ISSN: 2236-1170)

and a kinetic method was performed, which each five minutes until 30 minutes, was monitored the loss of. All experiments were performed in triplicate.

To enable a comparison, was performed the same test with synthetic substance with antioxidant action. Thus, in $300 \mu \mathrm{L}$ of ethanolic solutions containing the synthetic antioxidants Trolox, BHA and $\mathrm{BHT}$ in concentrations ranging from 0.975 to $1.5 \mathrm{mg} \mathrm{mL}-1$ were added $2.70 \mathrm{~mL}$ of DPPH solution. Spectrophotometric measurements of the kinetics involved were monitored at $664 \mathrm{~nm}$ in triplicate.

\section{RESULTS AND DISCUSSION}

\subsection{Extraction Method x Chemical composition}

The secondary metabolism of plants is a plant defense mechanism responsible for the biosynthesis of complex structures such as alkaloids, terpenoids and phenylpropanoids derivatives. The wealth of secondary metabolites in plants is explained by the diversity of factors that stimulate its production, such as temperature, rainfall, seasonality, atmospheric composition, altitude, latitude, UV radiation, circadian rhythm, micronutrients, macronutrients, plant age and attacks by herbivores and pathogens (LUCKNER, 1984).

High Performance Liquid chromatography coupled with mass spectrometry detection (LC/MS) is one of the most powerful analytical tools for organic compound analysis. The LC/MS presents some advantages such as generation of chemical fingerprint for the compound of interest, structural information and molecular weight information that allows confirmation or identification of compounds, moreover to obtain quantitative data.

In mass spectrometry, gas molecules are ionized, accelerated by an electric field, and then separated according to their ratio of mass/charge $(\mathrm{m} / \mathrm{z})$. The mass spectrum is a histogram showing the relative abundance of each ion that strikes the detector equipment. The characteristic and only achieved for each compound mass spectrometry makes the most reliable method for confirmation of identity.

In chemical composition of ethanol extracts of the species analyzed there was a predominance of terpenoids compounds commonly found in the species of the genus Piper 


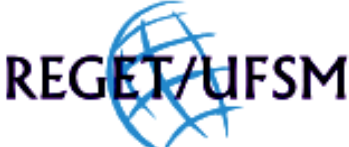

Rev. Elet. em Gestão, Educação e Tecnologia Ambiental

(e-ISSN: 2236-1170)

(MESQUITA et al., 2005). Table 2 shows the frequency of compound majority (over $4 \%$ ) found in each type of extraction. From the data presented can be observed that some were common to the three extracts as Caryophyllene- $\alpha$ and nerolidol. However, it is clear the distinction between the chemical composition of different extracts majority indicating that the extracts may have different pharmacological activities. Table 3 presents the main pharmacological activities described in the literature for the majority chemical compounds found in extracts of Piper aduncum.

Maceration consists in the extraction of plant material in a closed container at room temperature for an extended period, as the decoction extraction is performed under heating (SIMÕES, 2004). Ultrasound is mechanical waves that propagate in successive cycles of compression and rarefaction, forming cavitation bubbles that implode releasing a lot of energy, providing increased temperature and pressure, and these factors are responsible for the extraction of plant secondary metabolites (KORN , 2003). The procedure to obtain the vegetable extract must be chosen according to the purpose for which the product is intended for, since there are differences in the chemical composition of extracts obtained by these different processes and therefore in it pharmacological activity.

\subsection{Antioxidant activity}

Free radicals and reactive oxygen species play a fundamental role in cellular metabolism; however, when there are excess can cause oxidative stress, leading to tissue changes responsible for various diseases, including cancer (DRÖGE, 2002). Antioxidants are substances that react with free radicals preventing or reducing oxidative stress and subsequent tissue destruction (HALLIWELL, 1992).

Various methods are used to determine the antioxidant activity of extracts and isolated compounds, one of the most used is to assess the ability of the compound to sequester the free radical 2,2-diphenyl-1-picril-hydrazyl (DPPH •), which has purplish absorbent $517 \mathrm{~nm}$. The substance with antioxidant reduces the DPPH radical, forming picril-diphenyl-hydrazine which has yellow and thus disappears in $517 \mathrm{~nm}$ absorption (Brand-Williams et al., 1995). Thus, the percentage of DPPH • remaining in the reaction medium is inversely proportional to its antioxidant action of the compound, since the greater the consumption of DPPH by a sample and the greater its ability to reduce this compound. 


\section{REGETUFSM}

Rev. Elet. em Gestão, Educação e Tecnologia Ambiental

(e-ISSN: 2236-1170)

Table 4 shows the percentage of DPPH radical remaining after the tests performed with different concentrations of ethanol extracts of Piper aduncum and synthetic antioxidants. The Piper aduncum showed an antioxidant activity towards DPPH free radical which varied between the different extraction methods.

This result may be related to the chemical composition of the extract, and secondary metabolites identified as type sesquiterpene nerolidol, $\alpha$-caryophyllene, present in the sample of the two methods, and the antioxidant activity in an ultrasound bath and decoctions are at a higher expression in Figure 1.

For maceration results for antioxidant activity, the two methods was less expression. Although the compounds have in their composition in common, a compound which was identified only appeared in the maceration germacrene $D$ at a concentration of $17.16 \%$ in the test sample.

Figure 1 shows the activity of ethanol extract of Piper aduncum obtained with the techniques of decoction, maceration and ultrasound in the presence of free radical DPPH in a time of 30 minutes. It can be observed that small concentrations of the extract, this already shows scavenging activity. In this graph it can be seen that even at different concentrations, Trolox, BHA and BHT antioxidant activity exhibit a few minutes of reaction.

\section{Concluding remarks}

Food preservatives and antioxidants, cosmetic may be substituted by extracts from plants that antioxidant is tested. The equivalence of the extract of Piper aduncum to traditional antioxidants tested lead us to believe a potential replacement for synthetic extract these compounds, requiring, however, more study on the plant health and biosecurity. 


\section{REFERENCES}

ADIO, A.M. Trans-b-Elemene and related compounds: occurrence, synthesis, and anticancer activity. Tetrahedron 65 (2009) 5145-5159.

Arruda, D. C.; Alexandri, F. L. D; Katizin, A. M, \& Uliana, S. R. B. Antileishmanial Activity of the Terpene Nerolidol. Antimicrobial Agents and Chemotherapy, vol. 49. no 5., p.1679-1687, may, 2005.

Bastos, Cleber. N; Albuquerque, Paulo. S. B; Efeito do Óleo de Piper aducum em pós - colheita de Colletrotrium musae em Banana. Revista de Fitopatologia Brasileira 29; 555-557. 2004.

Brand-Williams W.; Cuvelier M. E. ; Berset C. Use of a Free Radical Method to Evaluate Antioxidant Activity. Lebensm.-Wiss. u.-Technol, 28.25-30 1995.

CHRISTENSEN, Lars P; BRANDT, Kirsten. Bioactive polyacetylenes and analysisin food plants of the Apiaceae family:Occurrence, bioactivity. Journal of Pharmaceutical and Biomedical Analysis, v.41 683-693, 2006.

COIMBRA, R. Manual de fitoterapia. 2 ed. Belém: CEJUP, 1994.

Cunico, M. M; Lopes, A. R.; Côcco, L. C.; Yamamoto C. I.; Plocharski, R. C. B.; Miguel, M. D.; Júnior, A. G.; Auer, C. G.; Miguel, O. G. Phytochemical and antibacterial evaluation of esencial oils from Ottonia matiana miq. (Piperacae). São Paulo. J. Braz.Chem Soc. v. 18, n 1. 2007.

DRÖGE, W. Free radicals in the physiological control of cell function. Phys. Revista, v. 82, p. 47-95, 2002.

FAZOLIN, M.; Estrela, J.L.V.; Catani, V.; De lima, M.S.; Alécio, M.R. Toxicidade do óleo de Piper aduncum L. a adultos de Cerotoma tingomarianus Bechyné (Coleoptera: Chrysomelidae). Neotrop. Entomol., v 34(3): p 485-489. 2005.

Florão, A. Avaliação de Atividades Biológicas de óleos Essenciais de Quatro espécies de Baccharis Astearaceae. 2006.Dissertação á obtenção de grau de Mestre em Ciências Farmacêuticas ,Programa de Pós - Grduação em Ciências Farmacêuticas - Área de Análises Clínicas, Setor de Ciências da Saúde, Universidade Federal do Paraná.

HALLIWELLI, B. Reactive oxygen species and the central nervous system. Jornal Neurochem, 59: 1.609-23, 1992.

Howard, 2003 


\section{REGEXJAFM}

Rev. Elet. em Gestão, Educação e Tecnologia Ambiental

(e-ISSN: 2236-1170)

KOBAEK-LARSEN, M.; CHRISTENSEN, L.P.; VACH, W.; RITSKES-HOITINGA, J.; BRANDT, K. Inhibitory Effects of Feeding with Carrots or (-)-Falcarinol on Development of Azoxymethane-Induced Preneoplastic Lesions in the Rat Colon. J. Agric. Food Chem. 2005, 53, 1823-1827.

Klopell F.C.; Lemos M; Souza, J.P.B, Comunello, E. Maistro, E. L., Ba stos, J.K., Andrade, S.F. Nerolidol an Antiulcer Constituint from the Essencial Oil of Baccharis dracunculifolia DC(Astearacea). Z. Naturforsch 62 c, 537-542, 2007.

KORN, Mauro; ANDRADE, Marta; V. A. S; BORGES, Sivanildo S; Procedimentos Analíticos Assistidos por Ultra-Som. Ver. Analítica. n 03 Fev, 2003.

LINK et al. Inhaled linalool-induced sedation in mice. Phytomedicine 16 (2009) 303-307.

LUCKNER, M. (1984) Secondary metabolism in microorganisms, plants and animals. 2nd Ed.Springer Verlag, Berlin.

MESQUITA, J.M.O.; CAVALEIRO, C.; CUNHA, A.P.; LOMBARDI; J.A.; OLIVEIRA, A.B. Estudo comparativo dos óleos voláteis de algumas espécies de Piperaceae. Revista Brasileira de Farmacognosia v.15(1): p 6-12, Jan./Mar. 2005.

NAVICKIENE, H.M.DI; MORANDIM, A.A; ALÉCIO, A.C; REGASINI, L.O; BERGAMO, D.C.B; TELASCREA, M.I; CAVALHEIRO, A.J.C; LOPES, M.N; BOLZANI,V.S.I; FURLAN, MI; MARQUES, M.O.MI; YOUNG, M.C.M.; J. KATO, M.J. Composition and antifungal activity of essential oils from Piper aduncum, Piper arboreum and Piper tuberculatum São Paulo. Quím. Nova. vol. 29 no.3. May/June, 2006. RÜDIGER, A.L.; SIANI, A.C.; VEIGA, V.F.; The Chemistry and pharmacology of the South America genus Protium Burm. f. (Burseraceae). Pharmacognosy Reviews Vol 1, Issue 1, Jan- May, 2007. SIMÕES, C.M.O; SCHENHEL,E.P; GOSMANN,G; MELO J.C.P;MENTZ,L.A; PETROVICK,P.R. Farmacognosia :da Planta ao Medicamento .5 ed. Florianópolis. Editora da UFRGS/UFSC, 2004.

FLÁVIA NEGROMONTE SOUTO-MAIOR, FABÍOLA LÉLIS DE CARVALHO, LIANA CLÉBIA SOARES LIMA DE MORAIS, SUELI MENDONÇA NETTO, DAMIÃO PERGENTINO DE SOUSA, REINALDO NÓBREGA DE ALMEIDA. Anxiolytic-like effects of inhaled linaloolwoxide in experimental mouse anxiety models. Pharmacology Biochemistry and Behavior. Volume 100, 2011, Pages 259-263.

SOUZA,P.J;Barros, C.A.L.;Rocha, J.C.S.;Lira, D.S.;Monteiro,G.M.;Maia J.G.S. Avaliação toxicológica do óleo esencial de Piper aduncum L. Revista Brasileira de Farmacognosia 18(2)217-221,Abril/jun, 2008. 


\section{REGETHFSM} Rev. Elet. em Gestão, Educação e Tecnologia Ambiental

(e-ISSN: 2236-1170)

SOUZA, T.J.T.; Apel, S.B; Bordgnon,S.; Matzenbacher, N,I; Zuanazzi, J.A.S.; Henriques, A.T.Composição Química e atividade do óleo volátil de Eupatorium polystacyum DC. Revista Brasileira de Farmacognosia ,p 368-372, jul/set, 2007.

Vallilo, M.L., Bustillios, O. V, AGUIAR, O.T. Indentificação de terpenos no óleo essencialdos frutos de Campomanesia adamantium (Cambessédes) O. Berg. - MYRTACEAE. São Paulo Rev. Inst.Flor. v.18 ,n único, p 15-22 dez., 2006.

VAN DEN BERG ME. Plantas medicinais na Amazônia: Contribuição ao seu conhecimento sistemático. 2 ed. Belém: Museu Paraense Emílio Goeldi, 1993.

Yuncker,t,g.The piperaceae of brasil. HOEHNEA 2: 19-366.1972.

Table 1 - The extraction conditions

\begin{tabular}{cccc} 
Method & $\begin{array}{l}\text { Vegetable drug:Ethanol } \\
(\mathrm{g}: \mathrm{mL})\end{array}$ & Time & Temperature \\
\hline Maceration & $15: 250$ & 7 days & Room \\
Ultrasonic & $15: 250$ & 4 hours & $20 \circ \mathrm{C}$ \\
Decoction & $15: 250$ & 5 hours & $100 \circ \mathrm{C}$ \\
\hline
\end{tabular}


REGETATFSM

Rev. Elet. em Gestão, Educação e Tecnologia Ambiental

(e-ISSN: 2236-1170)

Table 2 - Experimental conditions and results obtained for this work.

\begin{tabular}{|c|c|c|c|c|c|c|}
\hline \multirow{3}{*}{ Compound } & \multicolumn{6}{|c|}{ Extraction method } \\
\hline & \multicolumn{2}{|c|}{ Maceration } & \multicolumn{2}{|c|}{ Ultrasonic } & \multicolumn{2}{|c|}{ Decoction } \\
\hline & Retention time & $\%$ & Retention time & $\%$ & Retention time & $\%$ \\
\hline Cadinene-cis- $\gamma$ & - & - & - & - & 14.59 & 15.39 \\
\hline Cadinene- $\delta$ & 15.25 & 6.01 & - & - & 15.26 & 5.73 \\
\hline Calacorene- $\alpha$ & - & - & 14.56 & 5.41 & - & - \\
\hline Caryophyllene & 13.25 & 6.78 & 13.13 & 7.56 & - & - \\
\hline Caryophyllene- $\alpha$ & 13.94 & 7.49 & 13.80 & 8.25 & 13.93 & 6.06 \\
\hline Elemene - $\beta$ & 12.58 & 3.12 & - & - & - & - \\
\hline Elemene $-\gamma$ & 14.92 & 14.48 & - & - & 14.91 & 13.49 \\
\hline Falcarinol & - & - & 15.05 & 6.06 & - & - \\
\hline Germacrene D & 14.59 & 17.16 & - & - & - & - \\
\hline Linalool & - & - & 6.36 & 8.00 & - & - \\
\hline Linalool oxide & - & - & 5.79 & 4.34 & - & - \\
\hline Nerolidol & 16.03 & 13.41 & 15.78 & 18.45 & 16.06 & 15.24 \\
\hline Santalene- $\alpha$ & - & - & - & - & 13.24 & 5.63 \\
\hline
\end{tabular}




\section{REGETALSM}

Rev. Elet. em Gestão, Educação e Tecnologia Ambiental

(e-ISSN: 2236-1170)

Table 3 - Pharmacological Activities of the main chemical components present in extracts Piper aduncum.

\begin{tabular}{|c|c|}
\hline Compound & Pharmacological Activity \\
\hline Cadinene-cis- $\gamma$ & Anti-inflammatory (RÜDGER et al., 2007). \\
\hline Cadinene- $\delta$ & Bactericidal and anti-carcinogenic (SOUZA et al., 2007). \\
\hline Calacorene- $\alpha$ & Antimicrobial (referência). \\
\hline Caryophyllene and caryophyllene $-\alpha$ & Anti-inflammatory (VALLILO et al., 2006) e antitumoral activity (RÜDGER et AL., 2007). \\
\hline Elemene $-\beta$ & $\begin{array}{l}\text { Antimicrobial (CUNICO et al., 2007), activity against cancer of the brain, liver, breast, lung, and other tissues as well as of leukemia (ADIO, } \\
\text { 2009). }\end{array}$ \\
\hline Elemene $-\gamma$ & Anti-inflammatory, analgesic, antinociceptive, hepatoprotective, anti-itching and gastroprotective (RÜDGER et AL., 2007). \\
\hline Falcarinol & $\begin{array}{l}\text { Anticancer (KOBAEK-LARSEN, 2005), anti-inflammatory, anti-platelet-aggregatory, antibacterial, and antifungal (CHRISTENSEN \& BRANDT, } \\
\text { 2006) }\end{array}$ \\
\hline Germacrene-D & Antimicrobial (Nayickiene et al., 2006; Cunico, 2007), fungicide and insect signaling (SOUZA, 2007). \\
\hline Linalool & Anti-inflammatory, antitumor activity in vitro (RÜDGER et AL., 2007) and sedative (LINK et al., 2009). \\
\hline Linalool oxide & $\begin{array}{l}\text { Antimicrobial, antifungal (HOWARD, 2003), anti-inflammatory, inhibiting the production of nitric oxide, antitumor activity in vitro } \\
\text { (RÜDGER et AL., 2007) and anxiolytic-like effects (SOUTO-MAIOR et al., 2011). }\end{array}$ \\
\hline Nerolidol & $\begin{array}{l}\text { Inhibits the growth of species of the genus Leishmania in vitro (ARRUDA et al., 2005); antiulcer action (KLOPELL et al., 2007), anti- } \\
\text { inflammatory activity in vitro (RÜDGER et AL., 2007). }\end{array}$ \\
\hline Santalene- $\alpha$ & $\begin{array}{l}\text { Antimicrobial (FLORÃO, 2006), antitumor activity in vitro, antinociceptive, anti-inflammatory and inhibiting the production of nitric oxide } \\
\text { (RÜDGER et AL., 2007). }\end{array}$ \\
\hline
\end{tabular}


REG脸集FS

Rev. Elet. em Gestão, Educação e Tecnologia Ambiental

(e-ISSN: 2236-1170)

Table 4 - Percentage of DPPH radical remaining in the tests performed with different concentrations of ethanolic extracts of Piper aduncum and synthetic antioxidant substances.

\begin{tabular}{ccccccc}
\hline \multirow{2}{*}{$\begin{array}{c}\text { Concentration }(\mathrm{mg} \\
\mathrm{mL}-1)\end{array}$} & \multicolumn{5}{c}{ Percentage of DPPH remaining } \\
\cline { 2 - 7 } & Maceration & Ultrasonic & Decoction & BHT & BHA & TROLOX \\
\hline 0.0975 & 77.9 & 53.4 & 25.3 & 62.4 & 4.3 & 3.8 \\
0.1875 & 42.0 & 38.9 & 14.4 & 44.9 & 5.0 & 3.8 \\
0.375 & 30.0 & 22.2 & 16.3 & 24.7 & 5.7 & 3.8 \\
0.75 & 14.5 & 14.5 & 14.5 & 9.3 & 5.5 & 3.9 \\
1,5 & 11.3 & 11.3 & 11.3 & 5.1 & 5.9 & 4.0 \\
\hline
\end{tabular}

Figure 1 - Antioxidant activity of three Piper aduncum extracts and other antioxidants as measured by DPPH method. Lower percentage of DPPH radical remaining indicates high antioxidant activity.

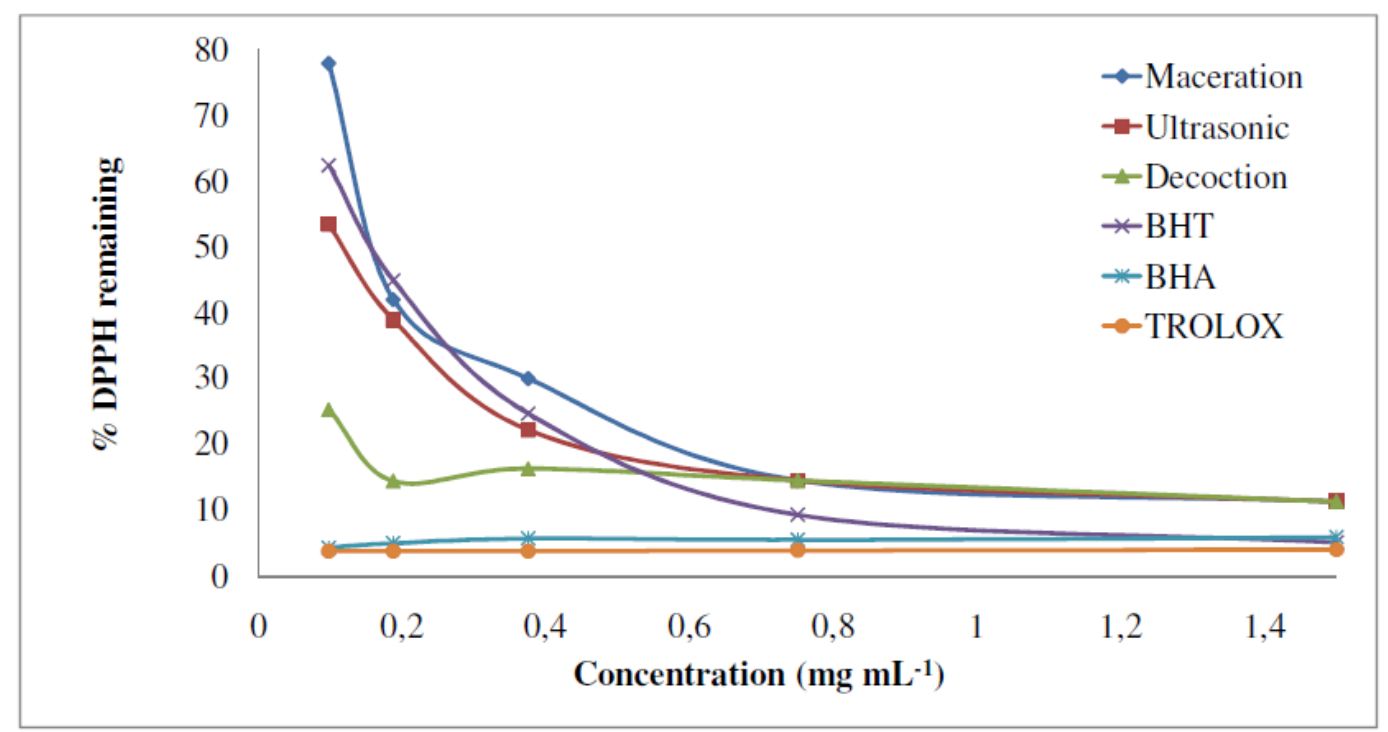


Fig - Antioxidant activity of Piper aduncum, BHA, BHT E TROLOX at different concentrations and considering 30 minutes of time reaction.

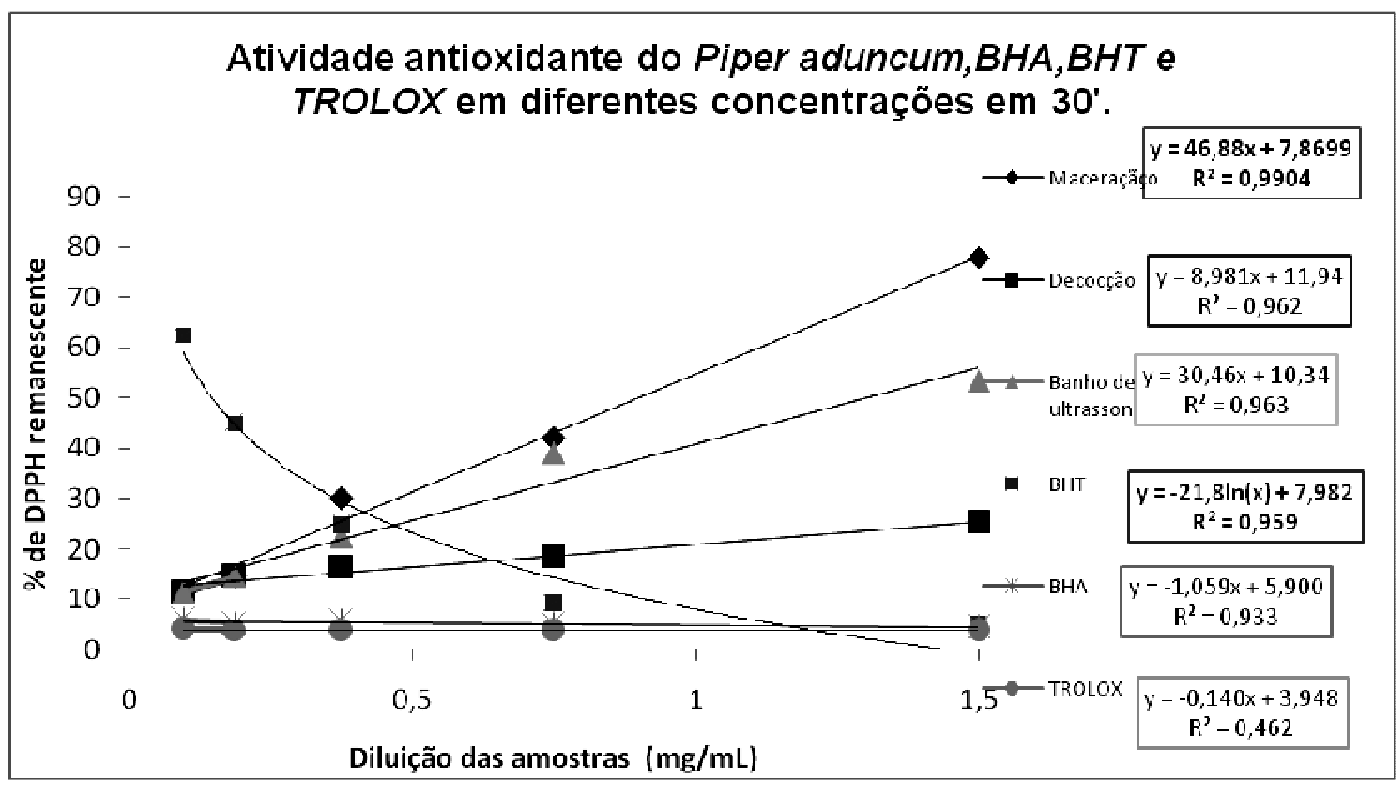

